\title{
Modifications in the chemical compounds and sensorial attributes of Engraulis anchoita fillet during marinating process
}

\author{
Alterações químicas e sensoriais em filés de anchoita (Engraulis anchoita) durante o processo de marinado
}

\author{
Maria Isabel YEANNES ${ }^{1 \star}$, Maria Rosa CASALES ${ }^{1}$
}

\begin{abstract}
Marinated fish are fish products preserved by the combined action of salt and organic acids. The objective of this work was to analyze the variations in the chemical compounds of anchovy fillets that give them sensorial characteristics during the marinating process of Engraulis anchoita. The protein content decreased slightly and the TVB-N level decreased significantly in both the brining and marinating stages. In the marinating stage an increase in the total free aminoacids was observed. The NBV level in the brining and marinating solutions increased during these stages due to the solubilization of the non-protein nitrogenous compounds and the degradation of some protein compounds. The decrease of the contents of protein and TVB-N, and the increase of the acidity and the free aminoacids content during the marinating process give the marinated fillets the characteristic texture and aroma.

Keywords: anchovy; marinating; processing; effects.
\end{abstract}

\section{Resumo}

Peixes marinados são produtos obtidos pela ação combinada de sal e ácidos orgânicos. O presente estudo teve como objetivo avaliar as alterações químicas e sensoriais em filés de anchoita (Engraulis anchoita) durante o processo de marinado. O conteúdo de proteína apresentou decréscimo significativo durante a salga. O teor de Bases Voláteis Totais-N-BVT, apresentou uma diminuição considerável durante a salga e marinacão. Na fase de marinado, foi observado um aumento em aminoácidos livres totais. Foi constatada a presença de N-BVT na salmoura e na solução oriunda do processo de obtenção de marinado, devido à solubilização de nitrogênio não protéico, que podem ter sido acrescidos de alguns compostos de degradação protéica. A redução do conteúdo de proteína e N-BVT e o aumento de acidez e de aminoácidos livres gerados durante ou processo de elaboração do marinado fazem com que os filés marinados adquiram textura e aroma característicos.

Palavras-chave: anchoita; marinado; processamento; efeitos.

\section{Introduction}

Marinated fish are products preserved by the combined action of salt and organic acids. Usually, acetic acid and salt are added to the fish to retard the action of bacteria and enzymes and to change the taste and textural properties of raw material (MEYER, 1965; Mc LAY, 1972; POLIGNE; COLLINGAN, 2000; BISPO et al., 2004; PONS-SANCHEZ-CASCADO et al., 2005, SALLAM et al., 2007).

In Argentina, the process of making cold marinated anchovies (Engraulis anchoita) has been developed using raw materials with different pre-treatment (fresh, frozen, and salted) and satisfactory products have been obtained in all the cases (YEANNES; CASALES, 1995). The effect of the process on the microorganisms has been studied, and it proved to be a safe product (FUSELLI et al., 1994). The typical microbiological flora of this product filled with different kinds of liquids (corn oil or acetic acid solution 2\%) was constituted by Lactobacillus paracasei paracasei 1, and Micrococcus spp. (FUSELLI et al., 1998).

During the marinating stage of this product two periods were differentiated, the "variable grade period", which corresponds to approximately the first 24 hours where the most abrupt physicochemical changes are presented, and the "constant grade period", which continues after the previous one until the end of the marinating process, in which the changes are evidenced clearly by their sensorial modifications (CABRER; CASALES; YEANNES, 2002).

The objective of this work was to analyze, during the marinating process, the variations in the chemical compounds of anchovy fillets that give them the specific sensorial characteristics.

\section{Materials and methods}

\subsection{Process}

Anchovy (Engraulis anchoita) caught in the Southwest Atlantic Ocean in September were frozen on board and stored at $-30{ }^{\circ} \mathrm{C}$ for further use in the marinating process. The process developed by Yeannes and Casales (1995) was applied (Figure 1). This process consists of the following stages: thawing, washing, heading, gutting and cutting off the tail, filleting, washing, brining (in a bath with $10 \%$ of sodium chloride-food grade-for 1 hour at room temperature $\left(18^{\circ} \mathrm{C}\right)$, fish: solution ratio 1:1), marinating

Recebido para publicação em 7/8/2007

Aceito para publicação em 1/5/2008 (002552)

${ }^{1}$ Grupo Preservación y Calidad de A, Departamento de Química, Facultad de Ciencias Exactas y Naturales, Consejo Nacional de Investigaciones Científicas y Técnicas - CONICET,

Universida Nacional de Mar del Plata, 7600 Mar del Plata - Bs As, Argentina,E-mail: myeannes@mdp.edu.ar

${ }^{*}$ A quem a correspondência deve ser enviada 


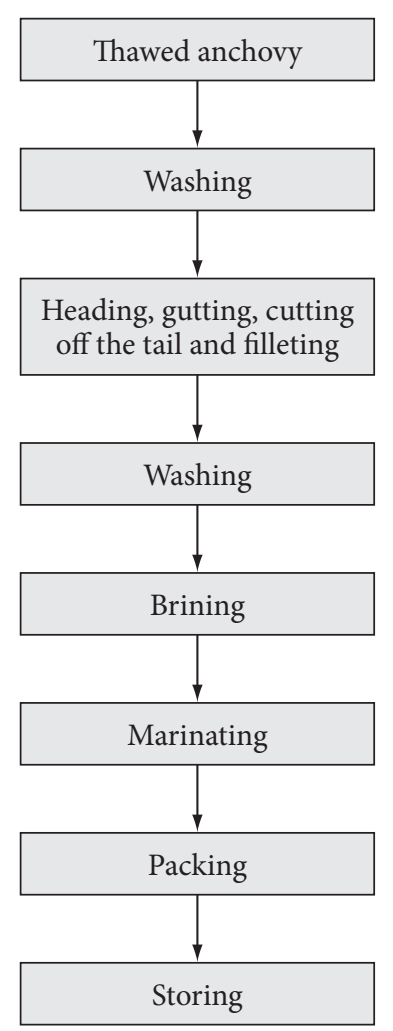

Figure 1. Marinating process of Engraulis anchoita.

in $10 \mathrm{~kg}$ closed, metal recipients at $20 \pm 1^{\circ} \mathrm{C}$ until the end point was assessed by sensory texture analysis (in a bath composed by $3 \%$ of acetic acid -Merk, pro analysis, 99-100\%, M = 60.05 g.mol ${ }^{-1}, 1 \mathrm{~L}=1.05 \mathrm{~kg}$ - and $10 \%$ of sodium chloride -food grade-, fish: solution ratio 1.3: 1), packing (in glass containers with corn oil), and finally, storing ( at $8{ }^{\circ} \mathrm{C} \pm 2{ }^{\circ} \mathrm{C}$ ).

Anchovy fillets were $9.69 \pm 0.29 \mathrm{~cm}$ long, $1.88 \pm 0.07 \mathrm{~cm}$ wide and $0.61 \pm 0.02 \mathrm{~cm}$ thick.

Yields of different stages were the following: heading, gutting, cutting off the tail an filleting stage was $62-65 \%$; brining stage equals to $105-109 \%$; and marinating $71-74 \%$, so the total yield was $44-48 \%$.

\subsection{Sampling}

The following samples were taken:

- Thawed anchovy fillet: to determine the Proximate Composition, TVB-N (Total Volatile Basic Nitrogen), water activity $\left(\mathrm{a}_{\mathrm{w}}\right)$, and sensorial analysis;

- At the end of the brining stage: to determine Proximate Composition, sodium chloride, TVB-N, $\mathrm{pH}$ and $\mathrm{a}_{\mathrm{w}}$; and

- At 12, 24, 48, 72, 96, 120, and 168 hours of marinating: to determine proteins, total free aminoacids, acetic acid, sodium chloride, TVB-N, and sensorial analysis. Besides, at the end of the stage (168 hours) the Proximate Composition, $\mathrm{a}_{\mathrm{w}}$ and $\mathrm{pH}$. wrere determined.

The TVB-N was also determined in the brine and in the marination solution.

\subsection{Physical and chemical analyses}

The water content was determined according to AOAC Sec. 984.25 (1990), the ashes for calcinations at $550{ }^{\circ} \mathrm{C}$ were determined as described by AOAC Sec. 945.46 (1993), the lipids extraction, according to AOAC Sec 922.06 (1990), and the total proteins were determined as described by AOAC Sec. 920.152 (1993). The sodium chloride was determined as chloride by the Mohr method (KIRK; SAWYER; EGAN, 1996). The acetic acid was determinated by titration with sodium hydroxide; $5 \mathrm{~g}$ of wet sample in $100 \mathrm{~mL}$ distilled water was heated for 3 minutes, and it was cooled to room temperature and filtered in a glass wool filter. The filtrate was titrated with to $0.5 \mathrm{~N}$ sodium hydroxide using phenolphtalein as the indicator (KIRK et al., 1996). The determination of total free aminoacids was carried out by the colorimetric method of Rosen (1957). The amount of $12.5 \mathrm{~g}$ of wet sample were placed in a beaker and added $50 \mathrm{~mL}$ of trichloroacetic acid 15\%. It was then placed in an ultrasonic bath for 10 minutes and in a centrifuge to $10,000 \mathrm{rpm}$ for 15 minutes. The sample was filtered and the supernatant was diluted 1:100. Aliquots of $0,2-0,4 \mathrm{~mL}$ were taken, adding $0.5 \mathrm{~mL}$ of buffer cyanide-acetate and $0.5 \mathrm{~mL}$ ninhidrina, and took volume $(1 \mathrm{~mL})$ with distilled water. The tubes were placed in a water bath at $100{ }^{\circ} \mathrm{C}$ for 15 minutes, and $5 \mathrm{~mL}$ of isopropyl alcohol-water was added. It was shook on a vortex mix cool at room temperature. The absorbance was determined in spectrophotometer at 570 nanometers. TVB-N was determined for the method of direct distillation (GIANNINI; DAVIDOVICH; LUPÍN, 1979). $10 \mathrm{~g}$ of sample were placed into the distillation flask with $300 \mathrm{~mL}$ of distilled water and added $5 \mathrm{~g}$ magnesium oxide, and $2 \mathrm{~mL}$ of antifoam solution. The samples were boiled and distilled into $50 \mathrm{~mL}$ of boric acid solution with an indicator (methil red: bromocresol green, 1:3) in a $500 \mathrm{~mL}$ beaker. After distillation $(230 \mathrm{~mL})$, the contents of the beaker were titrated with $0.1 \mathrm{~N}$ sulphuric acid.

All determinations were carried out in triplicate.

The $\mathrm{a}_{\mathrm{w}}$ was determined by a gravimetric technique using Conway dishes, $1 \mathrm{~g}$ of sample, and different saturated salt solutions of known water activity were used. The $\mathrm{a}_{\mathrm{w}}$ values were obtained by means of the ratios between loss and gain weight of the sample kept at a constant temperature at $25^{\circ} \mathrm{C}$ for 24 hours (SANCHEZ PASCUA; CASALES; YEANNES, 1994). The determinations were done in quadruplicate. The determination of the $\mathrm{pH}$ was carried out with a pHmeter with a glass electrode (Instrumental Parsec, Model Vega VI) according to AOAC Sec. 981.12 (1990).

\subsection{Sensorial analyses}

Thawed anchovy was sensorially assessed using the table developed by Darlan et al. (1981). This table takes into account the following characteristics: general aspect (pigmentation and iridescence of skin, presence of bloodspot), odor, belly burst and abdominal cavity, color and aspect of the fillet flesh, and color and aspect of the visceral cavity. The scores ranged from 81 to 100 for excellent quality, 61 to 80 for very good quality, 41 to 60 for good quality, and 30 to 40 for very poor quality.

During the marinating stage, the changes in texture, color, and acid and salted tastes were assessed. 
The changes in the texture were determined using a descriptive and structured scale (YEANNES; CASALES, 1995). The scale ranged from 1 for "inadequate texture for deficient or excess of marination" (typical of raw fish without marination or excessively soft respectively); to 4 for "the best degree of marination with a firm and consistent texture" (fillets are cut easily with a table fork). Point 2 in the scale corresponds to a dry and hard texture. It is resistant to cut with a table fork for deficient marinating, or it is soft and watery for marinating excess. Point 3 corresponds to the less hard, dry and fibrous texture for deficient marinating or less firm for excess of marinating.

Acid and salty tastes were individually evaluated using the structured scales. Scale for acid/salty tastes ranges from 0 "not acid/salty"; to 10 "extremely acid/salty". The intermediate points were the following: 2 for hardly perceptible; 4 for slightly acid/salty; 6 for moderately acid/salty; and 8 for very acid/salty (PEDRERO; PANGBORN, 1989).

To analyze the color another scale was used, which ranged from 0 for gray (raw) to 3 for white chalk and the intermediate points were the following: 1 for grizzly white, 2 for dirty white.

For the sensorial analysis of the marinated anchovy, the structured descriptive table developed by Yeannes and Casales (1995) was used. The attributes analyzed were: fillet color (external and internal); odor; flavor, and texture. The scores ranged from 0 points, for excellent quality, to 3 points, for rejected product (Table 1).

Six trained panelists participated in each tasting panel.

\section{Results and discussion}

The result of the sensorial analyses of thawed anchovy was 70 points, which corresponds to very good quality.

The proximate composition of the anchovy fillet and sodium chloride content in each stage of the process is shown in Table 2. These results are presented as follows: wet fish sample (g.100 g-1) and fish solids $\left(\mathrm{g} .100 \mathrm{~g}^{-1}\right)$.

Brining is used in fish products as a previous stage of preparation methods, such as drying and smoking, providing seasoning and an additional stability to the products. It is sometimes used in the process of marinating fish products. It is used in herring when the muscle is soft in order to harden it (Mc LAY, 1972 ) and also in the marinating process of Sprattus sprattus $L$. (LÓPEZ BENITO; SAMPEDRO, 1974). In the experiments with Engraulis enchrasicholus (SEN; TEMELLI, 2003) and with sardine (GÖKOĞLU; CENGIZ; YERLIKAYA, 2004), the brining stage was not used.

In the marinating process of Engraulis anchoita the effect of brining is very important from the sensorial point of view. In previous experiments, when the fillets were immersed directly in the marinating bath, it presented a granulate texture without sensorial acceptance (unpublished results). Moreover, the brining stage before the marinating stage improves the texture of the fillet avoiding the problem mentioned above.

Hamm (1960) outlined that in the presence of acid alone the $\mathrm{pH}$ of the muscle is on the acidic side of the isoelectric point and the electrostatic repulsion allows the increase in water holding capacity and the decrease in firmness. But, as salt is added, the repulsion decreases and the structure becomes firmer (RODGER; HASTINGS; BAILEY, 1984). This fact would explain the benefit effect of brining stage.

In these experiments, at the end of the brining stage the salt content was $20.46 \mathrm{~g} .100 \mathrm{~g}^{-1}$ of fish solids. This causes hardening of the tissue and avoids the excessive softening during the marinating process making the fish meat more consistent. The increment of water and salt contents observed are consistent with those obtained by Deng (1977), who pointed out that water

Table 2. Proximate composition and sodium chloride of the fillet in different stages of the marinating process.

\begin{tabular}{lccrrc}
\hline Sample & $\begin{array}{c}\text { Water } \\
\text { g.100 g }\end{array}$ & $\begin{array}{c}\text { Proteins } \\
\text { g.100 g }\end{array}$ & $\begin{array}{c}\text { Lipids } \\
\text { g. } 100 \mathrm{~g}^{-1}\end{array}$ & $\begin{array}{c}\text { Ashes } \\
\text { g.100 g }\end{array}$ & $\begin{array}{c}\text { Sodium } \\
\text { chloride } \\
\text { g. } 100 \mathrm{~g}^{-1}\end{array}$ \\
\hline Fillet & $78,64^{\mathrm{a}}$ & $17,90^{\mathrm{a}}$ & $2,90^{\mathrm{a}}$ & $1,12^{\mathrm{a}}$ & - \\
& $368,16^{\mathrm{b}}$ & $83,80^{\mathrm{b}}$ & $13,58^{\mathrm{b}}$ & $5,24^{\mathrm{b}}$ & - \\
Brining & $77,63^{\mathrm{a}}$ & $17,27^{\mathrm{a}}$ & $2,80^{\mathrm{a}}$ & $4,27^{\mathrm{a}}$ & $3,80^{\mathrm{a}}$ \\
fillet & $417,98^{\mathrm{b}}$ & $92,96^{\mathrm{b}}$ & $15,08^{\mathrm{b}}$ & $22,99^{\mathrm{b}}$ & $20,46^{\mathrm{b}}$ \\
Marinated & 71,98 & $18,32^{\mathrm{a}}$ & $3,20^{\mathrm{a}}$ & $5,46^{\mathrm{a}}$ & $4,97^{\mathrm{a}}$ \\
fillet & $329,47^{\mathrm{b}}$ & $83,86^{\mathrm{b}}$ & $14,64^{\mathrm{b}}$ & $24,99^{\mathrm{b}}$ & $22,75^{\mathrm{b}}$ \\
\hline
\end{tabular}

${ }^{a} \mathrm{~g} .100 \mathrm{~g}^{-1}$ of wet fish sample; and ${ }^{\mathrm{b}} \mathrm{g} .100 \mathrm{~g}^{-1}$ of fish solids.

Table 1. Sensorial evaluation of marinated anchovy.

\begin{tabular}{|c|c|c|c|c|c|}
\hline \multicolumn{2}{|c|}{ Characters } & \multicolumn{4}{|c|}{ Points } \\
\hline & & 0 & 1 & 2 & 3 \\
\hline \multirow[t]{2}{*}{ Fillet color } & External & $\begin{array}{l}\text { Full silvery. Skin without } \\
\text { damage. }\end{array}$ & $\begin{array}{l}\text { Silvery. Skin with } \\
\text { slight damages. }\end{array}$ & Yellowish. Skin with damages. & $\begin{array}{l}\text { Skin is scarce. Darker discolo- } \\
\text { ration. }\end{array}$ \\
\hline & Internal & White & $\begin{array}{l}\text { White dirty. Grizzly in } \\
\text { edges. Brown reddish } \\
\text { in the center. }\end{array}$ & $\begin{array}{l}\text { White yellowish or grizzly. } \\
\text { Center brown reddish diffused } \\
\text { toward the edges. Spotted. }\end{array}$ & $\begin{array}{l}\text { Brownish. Beige uniform or big } \\
\text { brown areas. Abnormal discolo- } \\
\text { ration. }\end{array}$ \\
\hline Smell & & $\begin{array}{l}\text { Typical of the preparation. } \\
\text { To fish pickled. }\end{array}$ & $\begin{array}{l}\text { Slightly sour. } \\
\text { To vinegar. }\end{array}$ & $\begin{array}{l}\text { Indefinite or to fish raw. Or very } \\
\text { sour and/or slightly rancid. }\end{array}$ & Rancid, pungenncy, unpleasant \\
\hline Flavor & & $\begin{array}{l}\text { Appetizing. Typical of the } \\
\text { preparation. }\end{array}$ & Soft. Slightly sour. & $\begin{array}{l}\text { To raw fish. Sour. Lightly salted. } \\
\text { Slightly rancid. }\end{array}$ & $\begin{array}{l}\text { Salted. Very sour. Bitter. Pungency. } \\
\text { Rancid. Abnormal flavors. }\end{array}$ \\
\hline Texture & & $\begin{array}{l}\text { Typical of the product. } \\
\text { Firm. Succulent. }\end{array}$ & $\begin{array}{l}\text { Firm or rather fibrous } \\
\text { or floury. }\end{array}$ & $\begin{array}{l}\text { Slightly soft or hard, and/or } \\
\text { fibrous. Rough, dry or watery. } \\
\text { Tends to be disrupted or wizened }\end{array}$ & $\begin{array}{l}\text { To raw fish. Hard or soft, gummy } \\
\text { and/or pasty. }\end{array}$ \\
\hline
\end{tabular}


migrates from the brine into the flesh of fish when the fillets are soaked in brine at concentrations up to $15 \%$.

It can be said that the brine bath had a bled effect and promoted the whitening of the fillet. The raw material water activity $\left(\mathrm{a}_{\mathrm{w}}\right)$ changed from 0.99 to 0.97 indicating that this stage has also a hurdle effect for microbial growth. TVB-N in the fillet decreased from 126.12 to $116.40 \mathrm{mg} .100 \mathrm{~g}^{-1}$ of fish solids and increased to $47.20 \mathrm{mg} .100 \mathrm{~g}^{-1}$ dry sample in the brine.

Acetic acid content and $\mathrm{pH}$ in the fillet at the end of brining and marinating stages are presented in Table 3 . Both results are important considering that acetic acid is a weak acid that promotes a decrease in $\mathrm{pH}$, no dissociate fraction of the molecule passes through the cellular membrane, and when the homeostatic mechanism is overcame it promotes a preservation effect.

The behavior of water, salt, and acid contents during the marinating stage are shown in Figure 2.

The salt content of the fillet remained stable during the marinating stage since the salt level reached in the brining stage and the decrease in salt concentration in the marinating solution by the outlet of water from the fillets. According to Kolakowski and Bednarczyk (2002), the acetic acid contained in the marinating solution caused the decrease in the water content of fillet. Besides, these results are in agreement with Borgstrom's (1968). The water activity $\left(\mathrm{a}_{\mathrm{w}}\right)$ at the end of marination was 0,96 .

Table 3. Acetic acid and $\mathrm{pH}$ of the fillet in the brining and marinating stages.

\begin{tabular}{lcl}
\hline \multicolumn{1}{c}{ Sample } & Acetic acid & $\mathrm{pH}$ \\
\hline Brining fillet & 0 & 6,5 \\
Marinated fillet & $1,20^{\mathrm{a}}$ & 4,2 \\
& $5,49^{\mathrm{b}}$ & \\
\hline
\end{tabular}

${ }^{\mathrm{a}} \mathrm{g} .100 \mathrm{~g}^{-1}$ of wet sample; and ${ }^{\mathrm{b}} \mathrm{g} \cdot 100 \mathrm{~g}^{-1}$ of fish solids.

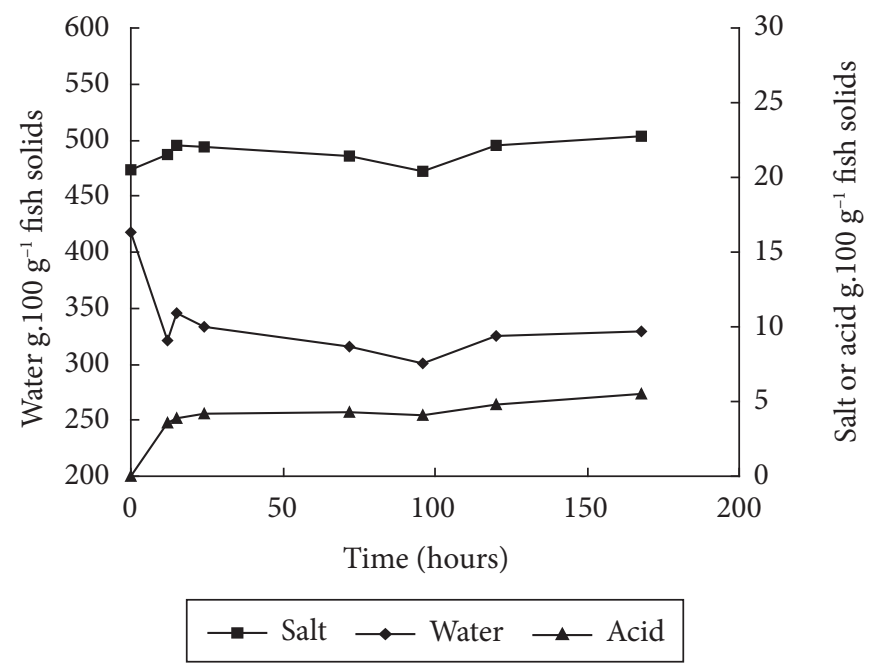

Figure 2. Changes in salt, acid, and water content of the fillet during the marinating stage.
In Figure 3, the changes in proteins and total free aminoacids (TFAA) contents during marination are presented. The decrease in the proteins content agrees with the results of Meyer (1965), Belitz and Grosch (1987), and Feeney (1977), who determined that the acid produces hydrolysis of the fish flesh. Microbial degradation of the proteins is not possible due to the high sensibility of microorganisms to the acid medium (MEYER, 1965). In a previous work, it was determined, for the same species, that there is no microbial development in the marinating stage (FUSELLI et al., 1998).

During the first day of marination, it was observed an abrupt decrease in the total free aminoacids (TFAA) followed by a gradual increase. Considering the process, this first behavior could be explained by the action of the acetic acid that promotes degradation of aminoacids in compounds of lower molecular weight. The increase could be caused by the increment in the activity of the tisular cathepsins that produces the unfolding of some muscular proteins in peptides and amino acids in the $\mathrm{pH}$ ranging from 4 to 4,5 (SHENDERYUK; BYKOWSKI, 1994).

The behavior of TBV-N content in the fillet during the marinating stage is shown in Figure 4.

As it can be observed, there is an abrupt decrease in NBV level from brined fillet to the fillet at beginning of the marinating stage. This value remained practically constant during the whole stage. This lower NBV content is consistent with the decrease in intensity of the fish flavor in relation to the brined fillet. The TVB-N in the fillet decreased from 116.40 to $59.57 \mathrm{mg} .100 \mathrm{~g}^{-1}$ fish solids while in the marination solution this value changed from 0 to $77.92 \mathrm{mg} .100 \mathrm{~g}^{-1}$ dry sample. The presence of TVB-N in this solution, according with Kilinc and Cakli, (2004), is due to the lixiviation of non-protein nitrogen compounds of the TVB-N as trimethylamine (TMA-N), dimethylamine (DMA-N) and ammonia $\left(\mathrm{NH}_{3}\right)$, and to the degradation of some proteic compounds (SHENDERYUK; BYKOWSKI, 1994).
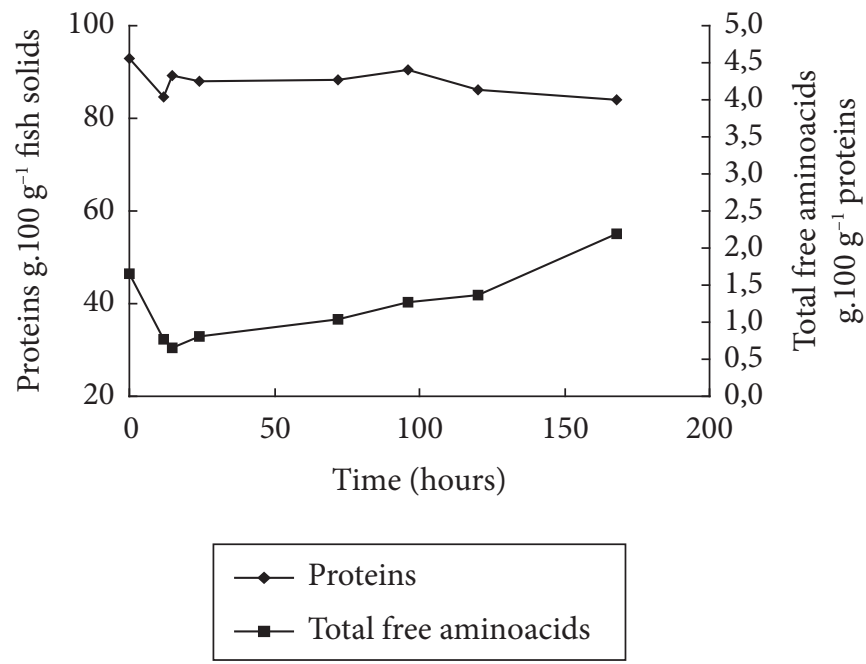

Figure 3. Changes in proteins and total free aminoacids during marinating stage. 
The behavior of the sensorial attributes of texture, color, and both tastes (acid and salty) during the 7 days of marination are shown in Figure 5.

The texture of the fillet at 7 days of marination was in the optimal point; the color was characteristic of the marinated product. It can also be observed that the perceived intensity of the salty taste decreased as the acid taste increased. This could be due to the fact that the acid taste masks the salty taste, which was demonstrated by Girao (1980).

At the end of marination (7 days) a reduction of $29 \pm 1 \%$ $\mathrm{w} / \mathrm{w}$ in the fillet was determined and it can be explained by the elimination of water, lipids, aminoacids, and other components. In herring, Borgstrom (1968) reported that during this stage around $2 \%$ of aminoacids can be lost (from the rupture of proteins that are dissolved in the marination solution) in addition to losing $14 \%$ of water, lipids, and other compounds resulting in an average loss of $25 \%$ in weight.

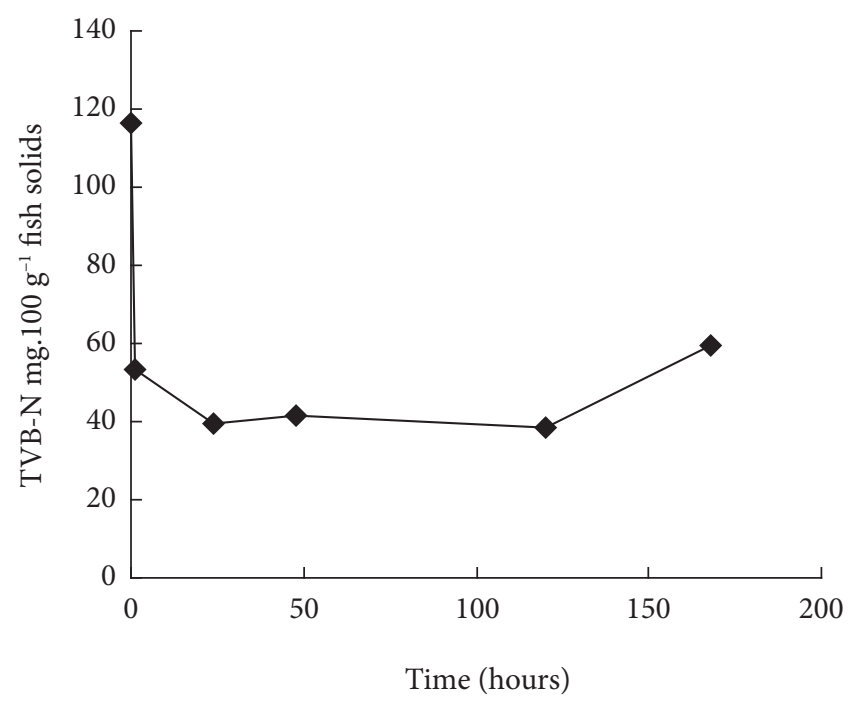

Figure 4. Behavior of TVB-N in the fillet during marinating stage.

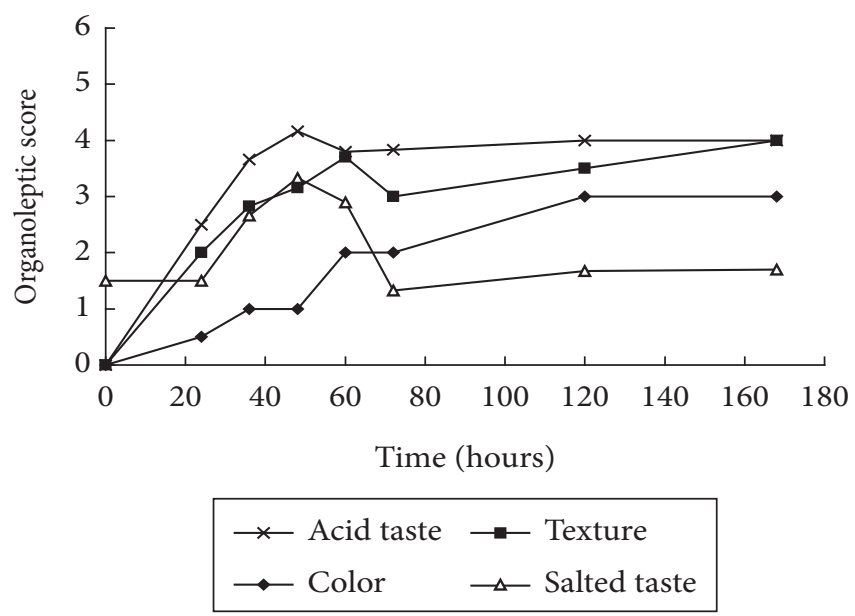

Figure 5. Sensorial attributes of the fillet during marinating stage.

\section{Conclusions}

The brining stage contributes to the characteristics of the marinated product having a bled effect that avoids the presence of bloodspot in the final product and causes modifications in the texture and flavor.

The decrease in proteins content and TVB-N and the increase of acidity and free aminoacids content during the marinating process gives the marinated fillets the characteristic texture and aroma.

\section{Acknowlogements}

The authors are grateful for the financial support provided by the Consejo Nacional de Investigaciones Científicas y Técnicas (CONICET) and Universidad Nacional de Mar del Plata (UNMDP) and to Lic. María E. Capaccione and Lic. Adriana I. Cabrer for the assistance in the sensorial and chemical analyses, respectively.

\section{References}

AOAC - Association of Official Analytical Chemists. Official Methods of Analysis. 15 ed. Washington, D.C., 1990.

AOAC - Association of Official Analytical Chemists. Official Methods of Analysis. 16 ed. Washington, D.C., 1993.

BELITZ, H. D.; GROSCH, W. Química de los Alimentos. Zaragoza: Acribia, 1987. p. 33-69.

BISPO, E. et al. Processamento, estabilidade e aceitabilidade de marinado de vongole (Anomalocardia brasiliana). Ciência e Tecnologia de Alimentos, v. 24, n. 3, p. 353-356, 2004

BORGSTROM, G. Chemical preservation. In: Principles of Food science. Food Technology. New York: Academic Press, 1968. v. 1, p. 290-322.

CABRER, A. I.; CASALES, M. R.; YEANNES, M. I. Physical and chemical changes of anchovy (Engraulis anchoita) flesh during marinating. Journal of Aquatic Food Product Technology, v. 11, n. 1, p. 19-30, 2002.

DARLAN, L. A. et al. Frescura y organolepsia de los productos de la pesca. II: Anchoíta (E. Anchoíta) capturada con red de cerco. Acta Bioquímica Clínica Latinoamericana, v. 12, p. 617-620, 1981.

DENG, J. C. Effect of freezing and frozen storage on salt penetration into fish muscle immersed in brine. Journal of Food Science, v. 42, n. 2, p. 348-351, 1977.

FEENEY, R. E. Chemical changes in food proteins. In: Evaluation of Proteins for Humans. Bodwell, C. E. (Ed.). Connecticut: The AVI Publishing Compani, Inc., 1977. p. 233-251.

FUSELLI, S. R. et al. Microbiology of the marination process used in anchovy (Engraulis anchoíta) production. Lebensmittel Wissenschaft und Technologie, v. 27, n. 3, p. 214-218. 1994.

FUSELLI, S. R. et al. Isolation and characterization of microorganisms associated with marinated anchovy (Engraulis anchoita). Journal of Aquatic Food Product Technology, v. 7, n. 3, p. 29-38, 1998.

GIANNINI, D. H.; DAVIDOVICH, L. A.; LUPÍN, H. M. Adaptación del método de uso comercial para la determinación de nitrógeno básico volátil en merluza (Merluccius hubbsi). Revista de Agroquímica y Tecnología de Alimentos, v. 19, n. 1, p. 55-60, 1979.

GIRAO, M. Los Sentidos, bases de la percepción. España: Alambra, 1980. 
GÖKOĞLU, N.; CENGIZ. E.; YERLIKAYA, P. Determination of the shelf life of marinated sardine (Sardina pilchardus) stored at $4{ }^{\circ} \mathrm{C}$. Food Control, v. 15, p. 1-4. 2004.

HAMM, R. Biochemstry of meat hydration. Advances in Food Research, v. 10, p. 144, 1960.

KILINC, B.; CAKLI, S. Chemical, microbiological and sensory changes in thawed frozen fillets of sardine (Sardina pilchardus) during marination. Food Chemistry, v. 88, p. 275-280, 2004.

KIRK, R.; SAWYER. R.; EGAN, H. Composición y Análisis de Alimentos de Pearson. 2 ed. México: Editorial Continental S.A.C.V., 1996.

KOLAKOWSKI, E.; BEDNARCZYK, B. Physical and sensory changes in headed and gutted baltic herring during inmersed salting in brine with the addition of acetic acid. Part 1. Weight losses, color of flesh and its sensory properties. Electronic Journal of Polish Agricultural Universities, v. 5, n. 2, p. 1-14. 2002.

LÓPEZ BENITO, M.; SAMPEDRO, G. Preparación del marinado de espadín. Informes Técnicos del Instituto de Investigaciones Pesqueras, v. 18, p. 3-14, 1974.

Mc LAY, R. Marinades. Torry Advisory Note, n. 56, p. 3-10, 1972.

MEYER, V. Marinades. In: Borgstrom, G. (Ed.). Fish as food. Processing: Part 1. New York: Academic Press, 1965. v. 3, p. 165-193.

PEDRERO, D. L.; PANGBORN, R. M. Evaluación Sensorial de los Alimentos: Métodos Analíticos. México: Alhambra, 1989.

PONS-SÁNCHEZ-CASCADO, S. et al. Influence of the freshness grade of raw fish on the formation of volatile and biogenic amines during the manufacture and storage of vinegar-marinated anchovies. Journal of Agricultural and Food Chemistry, v. 53, p. 8586-8592, 2005
POLIGNE, I.; COLLIGNAN, A. Quick marination of anchovies (Engraulis enchrasicolus) using acetic and gluconic acids. Quality and stability of the end product. Lebensmittel Wissenschaft und Technologie, v. 33, p. 202-209, 2000.

RODGER, G. et al. Diffusion properties of salt and acetic acid into herring and their subsequent effect on the muscle tissue. Journal of Food Science, v. 49, n. 7, p. 14-720, 1984.

ROSEN, H. A modified ninhydrin colorimetric analysis for amino acids. Archives of Biochemistry and Biophysics, v. 67, p. 10, 1957.

SALLAM, K. I. et al. Chemical quality and sensory attributes of marinated Pacfic saury (Cololabis saira) during vacuum-packaged storage at 4 C. Food Chemistry, v. 102, p. 1061-1070, 2007.

SÁNCHEZ PASCUA, G. L.; CASALES, M. R.; YEANNES, M. I. Preliminary Development of Intermediate Moisture, Pasteurised Mackerel (Scomber japonicus marplatensis) Chunk. Journal of Science of Food and Agriculture, v. 64, p. 199-204. 1994.

SEN, M. K. C.; TEMELLI, S. Microbiological and chemical qualities of marinates anchovy prepared with different vegetables additives and sauce. Revue de Médicine Véterinaire, v. 154, n. 11, p. 703-707, 2003.

SHENDERYUK, V. I.; BYKOWSKI, P. J. Salazón y escabechado de pescado. Tecnología de los Productos del Mar, Recursos, Composición nutritiva y Conservación. España: Ed. Acribia, 1994. Chap. 9, p. 211- 219.

YEANNES, M. I.; CASALES, M. R. Estudio de las variables de proceso de marinados de anchoíta (E. anchoíta). Alimentaria, Revista de Tecnología e Higiene de los Alimentos, v. 262, p. 87-91, 1995. 